\title{
Arnold Hauser e a Literatura Espanhola
}

\author{
Mario M. González ${ }^{1}$
}

\begin{abstract}
The reading of Arnold Hauser's work, in particular his book Der Manierismus, written in 1964, that deals with Spanish literature, allows us to overcome the usual classifications found in manuals of this area based only on chronological data. Hauser calls "Mannerism" the crisis of the Renaissance, distinguishing it from European Baroque movements. Some of the Spanish authors and their works from the sixteenth and seventeenth centuries respond to the characteristics of Mannerism, if one takes into account their perspectivism, the presence of paradox, their cerebral construction, the discovery of the modern reader, their autonomy as literary works, the overcoming of the classical genders, the use of dialog, etc, and can, therefore, be seen as the basis of the literary Modernity.
\end{abstract}

Keywords: Arnold Hauser; Mannerism; Spanish Literature; Modernity.

Resumo: A leitura da obra de Arnold Hauser, particularmente de seu livro Der Manierismus, de 1964, ao voltar-se para a história da literatura espanhola, nos permitiu superar as habituais catalogações embasadas apenas na cronologia, que predominam nos manuais dessa especialidade. Hauser chama de "Maneirismo" a crise da Renascença e distingue esse movimento dos Barrocos europeus. Alguns autores e obras espanholas dos séculos XVI e XVII, graças ao seu perspectivismo, à presença do paradoxo, à sua construção cerebral, à descoberta do leitor moderno, à sua autonomia como obras literárias, à superação dos gêneros clássicos, ao uso do diálogo, etc., respondem às características desse Maneirismo e, assim sendo, podem ser lidas como fundamentos da Modernidade literária.

Palavras-chave: Arnold Hauser; Maneirismo; Literatura Espanhola; Modernidade.

Para todos aqueles que, como eu, trabalhamos no ensino e na pesquisa de uma literatura estrangeira no Brasil, há sempre a necessidade de encontrarmos mecanismos de contextualização dessa literatura num âmbito mais universal, com o intuito de facilitar a

\footnotetext{
${ }^{1}$ Professor Titular de Literatura Espanhola, Universidade de São Paulo. mariogon@usp.br
} 
inserção dessa literatura no universo em que se inscrevem as referências do estudante brasileiro.

No caso específico da literatura espanhola, defrontamo-nos com a necessidade de aproximar do aluno todo um processo de desenvolvimento de uma literatura que inclui algumas das obras primas da literatura universal e que, por razões culturais e linguísticas, estão ou parecem estar muito próximas de nossos estudantes. Mas, aproximar o nosso aluno pelo mesmo viés apresentado pelos manuais de história da literatura espanhola produzidos na Espanha tropeça no inconveniente de que estes, mesmo que possam ser considerados excelentes, incluem uma grande quantidade de informações muitas vezes desnecessárias ao estudante brasileiro. E, ao mesmo tempo, deixam de oferecer outras informações (por já serem do domínio do estudante espanhol) que são imprescindíveis ao nosso estudante. Por outro lado, esses manuais carecem, muitas vezes, de uma perspectiva mais universalista na consideração das obras literárias espanholas.

É então necessário recorrer a teóricos e críticos da literatura universal que possam ancorar a reflexão sobre os textos a serem trabalhados. Gostaria de deixar aqui registrado o papel importantíssimo que no meu trabalho como professor de literatura espanhola na USP coube ao historiador e crítico da literatura e da arte Arnold Hauser ${ }^{2}$.

\footnotetext{
2 Arnold Hauser (Temesvár, Hungria, atual Romênia, 08/05/1892 - Budapest, 28/01/1978) estudou inicialmente Alemão e Línguas Românicas em Budapest, onde integrou a Sonntagskreis juntamente com seu amigo e colega Karl Mannheim e o filósofo Georg Lukács. Doutorou-se em Estética Românica e Germânica em 1918 e assumiu o cargo de professor na Universidade de Budapest. Em 1920, devido à Contrarrevolução Húngara, foi para a Itália, onde estudou Belas Artes. Entre 1920 e 1925 morou em Berlim. Em função da expansão do nacional-socialismo, em 1925 transladou-se a Viena. Lá trabalhou como gerente de promoções de uma companhia cinematográfica e começou a coletar material para seu livro Dramaturgie und Soziologie des Films que, no entanto, nunca concluiria. Foi também membro da Filmzensurbeirat (Conselho de Censura de Filmes da Áustria) entre 1933 e 1936 e lecionou Teoria e Tecnologia Cinematográfica na Volkshochschule de Viena. Em 1938, para fugir da perseguição nazista devido à sua origem judaica, instalou-se em Londres. Lá começou colaborando em revistas, com resenhas de filmes. Depois trabalhou na redação da Sozialgeschichte der Kunst und Literatur (História Social da Arte e da Literatura), que seria publicada primeiro em inglês, em 1951, e depois em alemão, em 1953. A aparição do primeiro volume do livro the valeu o reconhecimento no mundo acadêmico e, assim, lecionou, entre 1951 e 1957, como professor visitante da University of Leeds, ao mesmo tempo em que trabalhava no segundo volume da mencionada obra e na Philosophie der Kunstgeschichte. Após ter sido convidado por Theodor Adorno para ministrar uma conferência em Frankfurt, passou a receber convites do mesmo tipo, vindos de diversas universidades alemãs. Em 1958 publicou o segundo volume da Sozialgeschichte. Sendo professor convidado da Brandeis University, entre 1957 e 1959, escreveu Der Manierismus, livro publicado em 1964. Voltou a Londres em 1959, como professor do Hornsey College of Art. O terceiro e último volume da Sozialgeschichte seria escrito durante sua permanência como professor convidado da University of Ohio. Voltou à Hungria um ano antes de morrer. Com alguma exceção, sua principal produção foi escrita e editada em alemão antes de ser publicada em inglês:
} 
Sua obra foi traduzida para o espanhol, o que poderia ter facilitado a incorporação das suas teorias por parte dos estudiosos da literatura espanhola ${ }^{3}$. É muito interessante o resultado produzido pela aplicação das teorias de Hauser, - especialmente de seu conceito de Maneirismo -, à literatura espanhola, indo além das suas colocações sobre o assunto, às vezes muito en passant e às vezes de maneira muito genérica. Nesse sentido, é possível pensar que ele não tivesse uma vivência profunda da literatura espanhola. Em sua obra Der Manierismus, o autor limita-se inicialmente a catalogar Cervantes (na verdade, Dom Quixote) e Góngora (ou melhor, os poemas longos desse autor), como representantes do Maneirismo puro, e a Calderón (especificamente, El gran teatro del mundo e La vida es sueño), como representante do Maneirismo impuro, que misturaria elementos barrocos. Pelo caminho, deixa resvalar a opinião de que San Juan de la Cruz, como poeta, é maneirista; sustenta ainda que o pícaro nunca foi suporte de alguma obra que coubesse no Maneirismo. Hauser utiliza a personagem de Don Juan (ele parece referir-se ao personagem de Tirso de Molina) como um dos protótipos que encarnam a categoria maneirista do narcisismo. Mas, ao analisar a literatura maneirista na Espanha, o autor reduz os matizes antes estabelecidos ao incluir Cervantes, Góngora, Lope de Vega e Calderón como fiéis ao Conceptismo e também ao Culteranismo, as duas modalidades do Barroco literário espanhol. A catalogação de Hauser, assim, tornase um pouco confusa. Contudo, para nosso contexto argumentativo, isso não impede que sua explanação se torne importante ao apontar para a possibilidade de ler a literatura espanhola dos séculos XVI e XVII à luz de sua noção de Maneirismo.

Sozialgeschichte der Kunst und Literatur. 2 vols. München: C. H. Beck, 1953; em inglês, The Social History of Art. New York: Alfred A. Knopf, 1951. Philosophie der Kunstgeschichte. München: C. H. Beck, 1958; em inglês, The Philosophy of Art History. New York: Alfred A. Knopf, 1959. Der Manierismus: Die Krise der Renaissance und der Ursprung der Modernen Kunst. München: C. H. Beck, 1964; em inglês, Mannerism: The Crisis of the Renaissance and the Origin of Modern Art. 2 vols. London: Routledge \& Paul, 1965. Soziologie der Kunst. München: C. H. Beck, 1974; em inglês, The Sociology of Art. Chicago: University of Chicago Press, 1982. Cf. www.dictionaryofarthistorians.

${ }^{3}$ As principais obras de Arnold Hauser foram traduzidas para o espanhol e editadas e reeditadas diversas vezes pela editora Guadarrama, de Madri: Historia social de la Literatura y el Arte (Sozialgeschichte der Kunst und Literatur); Introducción a la historia del arte (Philosophie der Kunstgeschichte); Sociología del arte (Soziologie der Kunst); Arte y Sociedad (Philosophie der Kunstgeschichte); Origen de la literatura y el arte modernos (Der Manierismus: Die Krise der Renaissance und der Ursprung der Modernen Kunst). Der Manierismus foi traduzida para o português e editada pela editora Perspectiva, de São Paulo, com o título Maneirismo: a crise da Renascença e a origem da arte moderna. 
O conceito de Maneirismo (independentemente de sua definição por Hauser) custou a penetrar, ser aceito e utilizado pelos hispanistas em geral ${ }^{4}$. Para os estudos sobre artes e literatura, a confortável divisão do século XVI em duas etapas do período da Renascença e a outorga do rótulo de Barroco para o século XVII, ambos fundidos num único fenômeno batizado de "século(s) de ouro", eximiu os críticos e historiadores da necessidade de esmiuçarem as características desse período com maior precisão ${ }^{5}$. Foi, pois, fundamentalmente a crítica estrangeira que tentou quebrar essa uniformidade. Usar o conceito de Maneirismo para compreender esse espaço de tempo esbarra, contudo, no inconveniente da grande discrepância com que o conceito é tratado pelos diversos críticos. Segundo nossa linha de pesquisa, consideramos perfeitamente possível nos atermos à noção de Maneirismo enunciada por Hauser para se obter uma leitura muito mais dinâmica da literatura espanhola, substituindo barreiras cronológicas muito artificiais por critérios históricos bem mais flexíveis e aptos a uma melhor avaliação das relações entre os diversos autores e textos e o seu papel na história da literatura ${ }^{6}$. Ao aplicar a noção hauseriana de Maneirismo à literatura clássica espanhola, abre-se o caminho para uma catalogação dos autores e obras que permite uma leitura diferente da história da literatura espanhola dos séculos XVI e XVII. Basicamente, pode-se entender que, ao longo desses dois séculos convivem (não sempre, mas especialmente na segunda metade do século XVI e no terço inicial do XVII) duas ou até três correntes artísticas e literárias - a renascentista, a maneirista e a barroca -, sendo que um mesmo autor (e até a mesma obra) poderá estar vinculado a mais de uma delas. Isso permite identificar de maneira menos arbitrária autores ou obras que os manuais habitualmente não conseguem situar. Para alguns deles, La Celestina (1499-1502), de Fernando de

\footnotetext{
${ }^{4}$ O Maneirismo foi considerado durante muito tempo na Espanha como um fenômeno estrangeiro e mais próprio das artes plásticas. Assim, o Diccionario da RAE apenas em edições mais recentes incorporou o termo "manierismo", entendendo-o como um "estilo artístico difundido por Europa en el siglo XVI, caracterizado por la expresividad y la artificiosidad". Um outro dicionário, o Diccionario de uso del Español, de María Moliner registra: "Manera artística que enlaza en Italia en el siglo XVI el arte del renacimiento con el barroco; es un arte de corte, refinado, muy cargado de fantasía y algo rebuscado; es un ejemplo el arte de Veronés o El Tintoreto. Amaneramiento artístico".

${ }^{5}$ Para se ter uma noção da enorme diversidade de usos das diversas noções de Maneirismo pela crítica hispânica, é interessante consultar o livro de CARILLA (1983). Mas essa diversidade não afetou, por exemplo, os textos dos numerosos manuais de história da literatura espanhola editados ou reeditados no último quarto do século XX. A maioria ignora a noção de Maneirismo e repete a sabida fragmentação cronológica. Quando algum deles aplica a noção de Maneirismo, vê nele uma categoria a - histórica.

${ }^{6}$ Foi o que tentamos fazer em nosso livro Leituras de Literatura Espanhola, publicado em 2010.
} 
Rojas (1470/76?-1541), estaria “entre a Idade Média e a Renascença”; Cervantes (15471616), por sua vez, "entre a Renascença e o Barroco"; Lazarillo de Tormes (1552?) seria apenas uma anomalia; e para todos eles, San Juan de la Cruz (1542-1591) seria, forçosamente, um "poeta místico" e Luis de Góngora (1561-1627) um poeta "culterano", A leitura desses e outros autores à luz da noção de Maneirismo enunciada por Hauser não apenas resolve essas indefinições, impropriedades ou rigidez, mas outorga a eles uma dimensão e uma função que os manuais não chegam a identificar.

\section{1. $\bigcirc$ Maneirismo, segundo Hauser}

Para Arnold Hauser, na crise da Renascença, que seria o Maneirismo, os caminhos da arte afastam-se pela primeira vez daqueles da natureza. Em situação análoga, a arte moderna, depois, repete essa revolução, não apenas deformando a realidade natural, mas substituindo-a. Essa crise equivale à crise do Humanismo: perdeu-se a fé no homem (a Reforma Protestante introduz a predestinação; o conhecimento científico, com Copérnico, passa a ser relativo, da mesma forma que a moral na política, como constata Maquiavel). A crise decorre da pretensão da Renascença de simplesmente reinstalar a cosmovisão dos antigos sem levar em conta o aparecimento do Cristianismo. Para Hauser, com o Maneirismo acabam, ao mesmo tempo, os universos criados pela Antiguidade, pela Idade Média e pela Renascença. Mas, para o autor, Maneirismo não quer dizer apenas amaneiramento, embora os maneiristas estejam predispostos a ele: a petrificação do conceito a partir de uma fórmula que sublinha os modos afetados poderia deixar a impressão de serem apenas rebuscados. O Maneirismo é, formalmente, anticlássico. Ao mesmo tempo, porém, é classicista, assim como é, paralelamente, racionalista e irracionalista, naturalista e antinaturalista. O conceito de Maneirismo só pode ser entendido a partir da tensão entre esses pólos e outros paralelos a estes, ou seja, da união de oposições aparentemente inconciliáveis. Decorre dessa afirmação que uma

\footnotetext{
${ }^{7}$ Culteranismo é o termo usado pela crítica espanhola para designar uma suposta escola poética barroca espanhola do século XVII. O estilo dos poetas "culteranos" estaria caracterizado, entre outros traços, pela abundância de metáforas surpreendentes, o uso exagerado de léxico culto e pela complexidade sintática. Como veremos, seria mais adequado falar em "Gongorismo" para designar essa tendência (integrada por Góngora e seus imitadores), diferenciando-a do Barroco como tal que, por sua vez, identifica-se melhor com o chamado "Conceptismo", cujo maior expoente é Francisco de Quevedo (1580-1645).
} 
definição do Maneirismo tem que aludir necessariamente ao paradoxo (isto é, a formulação da tensão entre elementos artísticos antitéticos). Mediante essa forma de expressão surge sempre algo excêntrico, exaltado, refinado, insólito, exagerado, excepcional, incitante, atrevido e provocador.

O Maneirismo, porém, não é apenas um simples jogo formal de elementos discrepantes. A pugna entre as formas expressa também o princípio dialético básico do Maneirismo, que manifesta a impossibilidade de expressar alguma coisa univocamente. Tudo aquilo que se expressa através de extremos polarmente opostos e que se concretiza mediante a união paradoxal acaba por dizer alguma coisa com sentido de ser. Assim sendo, o Maneirismo não consegue se exprimir a não ser mediante paradoxos.

O paradoxo, por sua vez, está impregnado no pensamento da época: no Protestantismo, que vê o homem como um ser que poderá ser salvo para a eternidade sem que deva nem possa ter méritos para tanto, sendo, sim, imprescindível a fé, ou seja, a salvação depende de um fato irracional; na Economia, que leva à alienação do operário com relação ao produto do seu trabalho; na Política, onde Maquiavel registra a duplicidade da moral: uma para o monarca e outra para os súditos; e na Literatura, onde a tragédia dissocia falta e culpa e onde o humor considera as pessoas e coisas de dois lados opostos.

O Maneirismo em si mesmo é paradoxal, na medida em que coloca a insuficiência do pensamento racional e sabe que a realidade é inapreensível conceitualmente e, ao mesmo tempo, apesar do seu irracionalismo e ceticismo, não pode renunciar aos artifícios mentais, ao jogo com os problemas e aos interrogantes.

A novidade maneirista decorre do afastamento da natureza e de uma atitude consciente perante a tradição: supera-se a noção de moderno (que já existia na Idade Média, baseada numa noção linear do tempo, e que havia substituído, por sua vez, a noção circular do tempo mítico), que entendia o antigo como o apoio que nos permite ver mais longe do que viam aqueles que nos precederam. Nasce, assim, a necessidade de afastar-se da tradição clássica. Com isso, a arte perde seu caráter aproblemático, no sentido de imitação, e se descobre sua história. Dissolve-se, dessa maneira, a arte renascentista, pelo anticlassicismo (os modelos clássicos são imitados, porém com grande dose de subjetividade, abandonando-se a ideia da obra como um todo orgânico); pelo antinaturalismo (pela primeira vez, há uma deformação consciente e intencional 
das formas naturais, devido a uma vontade de expressão que abandona a imagem costumeira das coisas) e pelo nascimento do homem moderno (a Idade Moderna não nasce com a Renascença, porém com sua dissolução). A Renascença movimenta-se ainda dentro dos limites da Idade Média, e a Idade Moderna é construída com os escombros de ambas as épocas. A supervalorização da Renascença como oposição à Idade Média é uma invenção do liberalismo do século XIX.

Por último, para Hauser, Maneirismo não é igual a amaneiramento: o anticlassicismo do Maneirismo não deve ser confundido com um movimento que sempre se seguiria a todo classicismo (como adesão a modelos consagrados) em oposição a ele e que, assim, poderíamos ver repetido ao longo da História.

Hauser analisa depois a crise da Renascença nas ciências (Copérnico, Galileu, Kepler), na Filosofia (Montaigne), na Economia (o nascimento do capitalismo moderno), na religião (a Reforma), bem como as relações entre Protestantismo e capitalismo, Reforma e Contrarreforma, e a Reforma católica (que ele vincula essencialmente ao Maneirismo, mencionando o caso do pintor espanhol El Greco). Depois analisa a crise renascentista na política (Maquiavel, sua moral dupla e o realismo político decorrente). Do relativismo perspectivista de Maquiavel decorre a noção de “ideologia”, que Hauser estuda em Marx levando em conta a mediação de Kant, para assim chegar à noção de alienação (coisificação) exposta por Hegel, como marca da Modernidade, e analisar o papel do dinheiro, bem como a função das instituições.

Como consequência dos pontos acima levantados, Hauser analisa a arte do Maneirismo, que vê não tanto como um produto da alienação, mas como a expressão da angústia perante a alienação; a obra de arte é, segundo esse crítico, a tentativa de escapar da alienação e, por isso mesmo, não é arte alienada.

Dessa maneira, as personagens do Maneirismo são seres que se perguntam quem são porque sofrem uma forte crise de identidade e não sabem o que é autêntico e o que é aparência em si mesmos. A expressão desse conflito é o desengano ${ }^{8}$ que domina em todos eles.

\footnotetext{
${ }^{8}$ Entendemos que, no caso da literatura espanhola, caberiam melhor, para designar esse estado de espírito, os termos "decepção" ou "desilusão", reservando-se o termo "desengano" para o Barroco, por melhor conotar o sentido transcendente da existência humana.
} 
À alienação social que se instala com a crise da Renascença, para Hauser, corresponde em psicologia o narcisismo. De acordo com Freud, nele, a libido é retraída do mundo exterior e concentrada no próprio sujeito. A literatura maneirista, para Hauser, é composta por uma galeria de caracteres narcisistas que se prolonga até a literatura contemporânea: Dom Quixote, Dom Juan, Hamlet, Fausto. A descrição psicológica dos caracteres passa, então, a ser feita por um método moderno, que é uma criação do Maneirismo: não se parte da unidade lógica da personalidade, porém da discrepância de suas manifestações, acentuando-se as irracionalidades e as contradições de um caráter, que tornam impossível a univocidade. Os caracteres maneiristas são modernos, especialmente nesse sentido; são complexos na sua tentativa de evitar que o mundo exterior se imponha; suas contradições residem no fato de retrair seu amor do mundo e dos homens, ao mesmo tempo em que precisam destes como interlocutores, público ou vítimas.

As grandes criações literárias do Maneirismo (Dom Quixote, Dom Juan, Fausto, Hamlet, Otelo) têm em comum agir à margem da realidade, numa existência fictícia. Seu eu contém ou acredita conter um substituto da realidade; desse confronto nasce a invenção literária. Com base nessa catalogação, Hauser analisa as personagens de Dom Quixote, Dom Juan, Hamlet e Fausto, como manifestações do narcisismo maneirista. E fecha seu estudo com a análise da criação da tragédia moderna e a descoberta do humor pelo Maneirismo, exemplificando tais pontos através de Shakespeare e Dom Quixote, de Cervantes, respectivamente.

\section{Maneirismo e Literatura Espanhola}

A aplicação dos conceitos de Hauser ao universo da literatura espanhola dos séculos XVI e XVII resulta em uma abordagem muito enriquecedora, como já manifestamos anteriormente. Os conceitos empregados para descrever a literatura renascentista e barroca da época não esgotam as manifestações literárias desses séculos na Espanha. Nesse período, uma série de obras, que não chegam a constituir uma escola, estão marcadas por traços comuns, da mesma maneira que os seus autores. E são exatamente obras e autores que a crítica tradicional nunca soube encaixar dentro de um recorte 
meramente cronológico. Essas obras e autores são: La Celestina (1499/1502), de Fernando de Rojas (1470/76?-1541); o anônimo Lazarillo de Tormes (1552?); Don Quijote de la Mancha (1605-1615), de Miguel de Cervantes (1547-1616); a poesia lírica (particularmente os chamados "poemas maiores") de frei Juan de la Cruz (1542-1591); e a poesia de Luis de Góngora (1561-1627), particularmente, as Soledades e o Polifemo. Propomos entender essas obras como as manifestações mais evidentes de Maneirismo, segundo o conceito enunciado por Hauser.

Para começar, os autores mencionados podem ser considerados, de uma ou de outra maneira, como marginais ao sistema dominante, pautado pela imposição de uma monarquia absoluta por parte de Castela ao restante da Espanha e pela opção pelo catolicismo romano como base ideológica dessa monarquia e única opção religiosa permitida aos indivíduos. Essa marginalidade é bastante disfarçada, já que qualquer desvio mais notável seria severamente punido, mas parece-nos ser razão fundamental da procura, por tais autores, de uma linguagem diferenciada que é a expressão ambígua de um pensamento divergente.

Assim, Fernando de Rojas é um descendente de conversos (isto é, descendente de judeus convertidos ao cristianismo), fato que o marcava como cidadão de segunda categoria. Ele escreve uma única obra, La Celestina, em que pese seu enorme sucesso imediato. A obra, paródia dialogada de uma história própria das narrativas vinculadas ao amor cortês, apresentada com fins moralizantes pelo seu autor, é até hoje a obra mais polêmica da literatura espanhola, especialmente com relação ao seu sentido. Talvez nunca saibamos qual a verdadeira intenção de seu autor ao escrevê-la. Claramente, dista muito de ser uma visão cristã da existência. Mas seu pretenso moralismo fez com que, mesmo sofrendo, a partir de 1539, o expurgo de algumas frases relativas a aspectos vinculados ao dogma canônico, o texto circulasse com relativa liberdade, o que foi explicitamente referido pelos responsáveis pelo Index ${ }^{9}$, em 1640. Curiosamente, a proibição integral do texto aconteceria em fins do século XVIII: no ano de 1772, pouco mais de cinquenta anos antes do fim da Inquisição na Espanha; a denúncia de um eclesiástico provocou a interdição da obra de Rojas.

\footnotetext{
${ }^{9}$ O Index librorum qui prohibentur (“Catálogo de livros proibidos”) foi estabelecido pela Inquisição na Espanha, em 1559, e teve vigência, nesse país, até a abolição dessa instituição, em 1834.
} 
Lazarillo de Tormes é uma obra anônima que quebra o monopólio narrativo das alienantes novelas de cavalaria. E é uma clara denúncia da sociedade hipócrita da época. Talvez por isso, seu autor (possivelmente um erasmiano) cuidou de não revelar seu nome, sendo que esse enigma subsiste até os nossos dias. A obra veio à luz em 1552 ou 1553. Tratava-se de uma forte sátira que atingia não apenas a conduta pouco cristã dos eclesiásticos - categoria predominante entre os avaros, mesquinhos, hipócritas e corruptos amos de Lázaro -, mas visava a toda uma sociedade assentada no valor das aparências e, indiretamente, o Império todo-poderoso construído a partir dela. Em 1559, o livro foi incluído no Index. Assim sendo, até 1834, na Espanha só poderia ser lida uma versão censurada, publicada pela primeira vez em 1573.

Cronologicamente, encontramos depois o frade Juan de la Cruz (1542-1591), outro possível descendente de conversos, autor dos mais belos poemas líricos em espanhol do século XVI. Homem da Igreja, ele é, porém, um rebelde-submisso, cujas aspirações de santidade excederiam o previsto pela hierarquia eclesiástica. Assim, será sequestrado, preso e torturado por seus irmãos de religião. Escapa de ser um "desaparecido" do século XVI graças a uma fuga da prisão, tida como milagrosa. Seria depois excomungado, desterrado e processado pela Inquisição. Salva-se das penas porque morre. E a Igreja irá canonizá-lo depois, quando suas obras e sua fama induzam a isso. O segmento mais importante de sua poesia é de temática amorosa e carente de léxico hierático. Para o frade, o amor era a maneira de expressar a união do indivíduo com Deus prescindindo da intermediação institucional da Igreja. O frade teve que "traduzi-los" para textos em prosa e a Igreja, até hoje, quer que sejam lidos apenas como teologia em verso. A maioria dos críticos curvou-se a isso e rotulou o poeta como "poeta místico", numa inaceitável redução de sua pluralidade de sentidos.

Miguel de Cervantes, filho de uma modestíssima família quiçá de conversos em sua origem, nunca verá reconhecidos seus esforços iniciais pelas causas nacionais, quando foi ferido em combate e depois sequestrado por piratas. Sem o favor dos poderosos e sem muita opção, vale-se da literatura para criar seu mundo. Mas só nos anos finais de sua vida terá sucesso, o que não lhe significará nem o reconhecimento pelo sistema, nem uma vida menos angustiada. Os aliados do sistema seriam sempre seus inimigos. Morreria pobre, como vivera. Sua obra mais importante, Don Quijote de la Mancha, ao nosso entender, a sátira mais frontal ao sistema, seria a que, 
curiosamente, menos sofreria as consequências dessa atitude. Entendemos que tal fato decorre da escolha feita por Cervantes para sua obra: o caminho de uma ampla ambiguidade significativa. O leitor de Don Quijote é colocado perante um leque de opções de interpretação da realidade que o texto lhe apresenta. A mais explícita delas trata de uma paródia cômica dos livros de cavalaria. A maioria dos leitores contemporâneos de Cervantes parece ter aceitado esse sentido como o mais evidente, senão o único, do romance. A permanente ironia de Cervantes vale-se, no entanto, de um constante jogo com o paradoxo para deixar transparecer outros sentidos possíveis; o mais crítico deles poderia ser o de que a referida paródia não apontasse apenas aos livros de cavalaria, porém à aventura vivida pelo Império espanhol ao longo do século XVI, aventura da qual a nação começava a voltar para casa ${ }^{10}$. Chegar a esse sentido, porém, exigia um distanciamento histórico que não era fácil ter no meio da euforia imperial, à época ainda muito viva e muito forte.

Um outro escritor - de origem conversa também - que se embate com o sistema vigente é Luis de Góngora. Sua discordância em relação aos aspectos representativos do sistema está presente em sua poesia satírica. Ele é um eclesiástico, mas talvez aceite essa situação, bem como o favor de alguns poderosos (fato que o levou a reprovar a si próprio pelas concessões que algumas vezes fez) como única possibilidade de subsistência de uma vida marcada pela afeição ao jogo. Quando pode, ele foge de tudo isso e escreve os poemas mais complexos da literatura clássica espanhola. Em um deles - Soledad primera - condena explicitamente as expedições marítimas levadas a cabo por espanhóis e portugueses, entendidas por ele apenas como realizações sob o impulso da cobiça. Tem que enfrentar os adictos ao sistema, que jamais lhe perdoaram nem sua poesia diferente nem sua origem judaica. Após sua morte, sua poesia é publicada e logo depois recolhida pela Inquisição, que condena 45 poemas como pagãos, obscenos ou subversivos.

\footnotetext{
${ }^{10}$ A Espanha encabeçara, no século XVI, um dos maiores impérios da História. A persistência de um anacrônico sistema social e econômico, no qual o cavaleiro conquistador agia em defesa de um ideário religioso (com empresas bélicas de perfil muitas vezes quixotesco), em detrimento da formação de uma futura burguesia, levou a sucessivos fracassos políticos que, no século XVII, fragilizaram esse império, finalmente disputado pelas potências européias no começo do século XVIII, quando Espanha e suas colônias acabaram sendo subordinadas aos interesses da coroa francesa.
} 
Um dos mais importantes aspectos da produção desses autores é o seu caráter perspectivista. Se a redescoberta da razão na Renascença levara a perceber o relativismo do próprio conhecimento racional, a pluralidade de pontos de vista colocados como fundamento do texto literário atendia a esse relativismo. As obras literárias deixavam agora de ser a mensagem unívoca emanada da autoridade onisciente do seu autor para se transformarem em um espaço no qual o leitor se defrontava com uma diversidade de sentidos muitas vezes coexistentes, expostos na forma de paradoxos a serem resolvidos.

O ponto máximo dessa realização está no romance Don Quijote de Cervantes. Seu autor o fez preceder de um prólogo que é aberto por duas palavras nada inocentes: “Desocupado lector". Esse sintagma, já ele próprio ambíguo, aponta para o leitor que pega o livro para preencher um espaço de lazer, mas apela também para o leitor histórico, que até então, pouco ou nada tinha exercido seu papel de maneira ativa, já que recebia mensagens de predominante univocidade. $\mathrm{O}$ contrário começa a acontecer com Don Quijote. Um leque de diversas perspectivas da realidade - que ocupam os espaços entre as relativas noções de loucura e de sensatez - abre-se desde o início da obra; o leitor deverá optar entre elas e, mais ainda, entre os muitos significados dessa realidade literária plural.

Essa pluralidade já se encontrava em Celestina, a obra de Rojas, que hoje já não pode ser lida com sentidos excludentes (paródia do amor cortês, cômica fábula didáticomoralizante, tragédia do deus amor, manifestação subliminar pessimista do autor converso, etc.). A rica coexistência desses sentidos permite ao leitor optar por uma ou mais dessas possibilidades.

Esse caleidoscópio de visões também é inerente à ambígua construção da narrativa de Lázaro de Tormes, narrador-protagonista do Lazarillo de Tormes. Nela, a aparente univocidade do discurso em primeira pessoa esconde paradoxalmente a dualidade da personagem desdobrada em narrador, que culmina na contradição entre ambos. A partir dessa contradição, cabe ao leitor intérprete moderno perscrutar os possíveis sentidos da obra, que podem ir desde a pretensamente inocente narrativa da vítima dos seus amos até a mais forte denúncia do sistema.

Com maior força ainda, a ambiguidade desafiadora do leitor está nos textos poéticos que aqui elencamos. Encontra-se, por exemplo, na paradoxal linguagem amorosa da poesia de frei Juan de la Cruz. Nela, a alegoria metafórica traduzida, própria 
da literatura erudita da Idade Média e a posterior alegoria metafórica não traduzida da Renascença são substituídas pela construção poética (levemente alegórica ainda) mediante símbolos cujo sentido não é explicitado, multiplicando-se, assim, as possibilidades de leitura num grau máximo, o que é próprio da literatura da Modernidade. O amor é o tema permanente desses poemas. Mas a relação amorosa aparece exposta mediante símbolos e sem referentes espaciais ou temporais precisos. $\mathrm{O}$ frade poderia estar aludindo com eles à sua relação com a divindade. Os poemas, no entanto, são a construção de um universo em que todas as formas de amor podem sentirse representadas.

Um passo além seria dado por Góngora, que suprime a alegoria e, a partir de elementos da Renascença, cria um código para a poesia, código distante tanto das metáforas já gastas da Renascença, que ele substitui por outras renovadoras e por metáforas puras ou complexas, como de qualquer coloquialismo que reduzisse a pluralidade de sentidos. Seus dois longos poemas designados como Soledades expõem as andanças de um náufrago que convive acidental e brevemente com alguns guardadores de cabras, primeiro, e com alguns pescadores, depois. A base é narrativa, mas Góngora constrói um universo de intenso lirismo apoiado em um permanente uso de metáforas muito audaciosas. Junto a isso, o permanente uso de vocabulário de suma erudição e de um hipérbato próprio do latim cria quase que uma língua à parte, válida apenas para a poesia. Cria-se, assim, um universo autônomo para o poema, cuja leitura seria um secular enigma. Apenas poetas do século XX - os espanhóis da geração de García Lorca - seriam leitores capazes de perceber o avançadíssimo estágio a que Góngora levou, assim, a poesia.

Trata-se, dessa maneira, em todos esses casos, de textos elaborados a partir de um plano de composição que privilegia a base intelectual de sua construção. Não se trata de registros artísticos de uma realidade externa, mas de construções pensadas em função de um sentido, ou melhor, de uma pluralidade de sentidos. Como na pintura de El Greco, temos modelos colocados em função de sentidos que se pretende obter, mais do que de momentos detidos num decurso temporal, como preferiria a arte barroca. Da mesma maneira, privilegia-se, neles, a razão como meio de aproximação analítica à realidade literária, antes do que a emoção como mediadora para o prazer estético. 
Um último traço comum a todos esses autores é muito significativo. Em todos eles há um predomínio do diálogo como estrutura básica dos textos, estrutura que leva à permanente alternância dos pontos de vista e, assim, à possibilidade da explicitação do perspectivismo.

Na obra de Rojas, a importância do diálogo é tão grande que talvez seja uma das poucas unanimidades da crítica sobre Celestina e tenha levado algum crítico, como Gilman, a ver nela um puro diálogo agenérico. A ausência de narrador faz com que as personagens existam graças a esse diálogo, o que leva à construção de caracteres e não à simples exposição de trajetórias.

Já em Lazarillo de Tormes, o diálogo rompe de vez com a retórica. A fala coloquial invade a narrativa, encaixando-se nela com enorme facilidade, para carregar esta da oposição básica que o livro inaugura: a distinção entre pícaro e homem de bem, que Lázaro irá anulando na medida em que consegue se apoderar da aparência (e da fala, por conseguinte) dos seus amos. E esse diálogo sustenta o paradoxo que está por toda parte, nessa história de Lázaro que, depois de aprender a ver com um cego, termina não querendo ver a si próprio, feito caricatura da caricatura, com o que seu relato se transforma num romance.

Em Don Quijote de la Mancha, Cervantes acaba com o monólogo dos oniscientes historiadores das novelas de cavalaria. E, da oposição entre o fidalgo "louco" (o protagonista) e o camponês "sadio" (seu escudeiro) nasce o diálogo como base da estrutura do romance cervantino, diálogo plural que é a representação invertida de uma sociedade sem espaço para o diálogo. E, mais uma vez, o diálogo é o suporte do paradoxo. Porque cabe ao leitor tentar fixar a pluralidade de significados opostos que se espalham a partir dessa realidade ficcional.

Com frei Juan de la Cruz, em sua obra-prima, o Cántico Espiritual, temos um diálogo de amor. Um puro diálogo de amor montado para expressar a incrível contradição de tocar a eternidade sem ter morrido, um diálogo onde as palavras perdem definitivamente as limitações do dia-a-dia para poder chegar perto de expressar esse tremendo paradoxo.

Nas Soledades, de Góngora, há uma primeira base de diálogo no encontro do peregrino com a realidade diferente. Todo o poema tem como suporte o caráter estranho que o universo dos pastores, camponeses e pescadores apresenta para o peregrino e, ao 
mesmo tempo, o aspecto estranho que este oferece para os habitantes desse universo. $\mathrm{O}$ processo todo dos dois poemas é o de anulação dessas distâncias mediante o diálogo.

Por esse caminho, entendemos que, dentro desse recorte diferenciado da literatura espanhola dos séculos XVI e XVII, defrontamo-nos com obras que, notadamente críticas e diferenciáveis, são fundamentais para a Modernidade, na medida em que abrem as portas às realizações que marcarão essa nova etapa da literatura: a poesia lírica capaz de construir uma linguagem exclusiva; as duas vertentes do romance - a de primeira e a de terceira pessoas -, como a narrativa onde o leitor tem a última palavra; e a anulação moderna dos limites do teatro clássico.

Por trás desse fenômeno há um último grande paradoxo que pertence não à literatura, porém à história. Porque tanta criatividade, que aponta para a liberdade do escritor e do leitor, não nasceu da liberdade, porém da necessidade de Rojas, frei Juan dela Cruz, o anônimo autor de Lazarillo de Tormes, Cervantes e Góngora escaparem às limitações do sistema - e até das diversas formas de prisão - pelo espaço sem limites da ambiguidade do texto literário.

Dessa maneira, a leitura da obra de Arnold Hauser e a aplicação de suas teorias à literatura espanhola nos permitiram ler essa literatura - exatamente num dos seus momentos de maior relevância - de um modo que supera as catalogações meramente cronológicas que registramos na maioria dos manuais que a historiam. Ao mesmo tempo, algumas obras podem encontrar, assim, um espaço melhor definido em suas relações com outras e, mais ainda, serem entendidas em seu papel de fundadoras da Modernidade.

\section{Referências bibliográficas}

CARILlA, Emilio. Manierismo y Barroco en las literaturas hispánicas. Madrid: Gredos, 1983.

Cervantes, Miguel de. Don Quijote de la Mancha. Ed. de Francisco Rico, $3^{\mathrm{a}}$, Barcelona: Crítica, 1999. Ed. bilingüe español/português: D. Quixote de la Mancha. Trad. de Sergio Molina. São Paulo: Editora 34, 2002 / 2007 (2 vol.).

Cruz, San Juan de la. Poesía. Ed. de Domingo Ynduráin, Madrid: Cátedra, 1984. Ed. bilingüe español/português: Poesias Completas. Trad. de Maria Salete Bento Cicaroni. São Paulo: Embajada de España, 1991.

GóNGORA. Luis de. Soledades. Ed. de J. R. Beverley, Madrid: Cátedra, 1980. 
GonZÁleZ, Mario M. Leituras de Literatura Espanhola (da Idade Média ao século XVII). São Paulo, Letraviva/Fapesp, 2010.

HAUSER, Arnold. Der Manierismus: Die Krise der Renaissance und der Ursprung der Modernen Kunst. München: C. H. Beck, 1964. . Mannerism: The Crisis of the Renaissance and the Origin of Modern Art. 2 vols. London: Routledge \& Paul, 1965.

Maneirismo: a crise da Renascença e a origem da arte moderna. Trad. J. Guinsburg; Magda Franca. São Paulo: Perspectiva, 1993. 2ª edição.

Lazarillo de Tormes. Ed., introd. y notas de Francisco Rico, Madrid: Cátedra, 1987. Ed. bilingüe español/português: Lazarilho de Tormes. Trad. de Heloísa C. Milton e Antonio R. Esteves. São Paulo: Editora 34, 2005.

Rojas, Fernando de. La Celestina - Comedia o Tragicomedia de Calisto y Melibea. Ed. de Peter E. Russell. Madrid: Castalia, 1991. . A Celestina. Trad. Millôr Fernández. Porto Alegre: L\&PM Editores, 2008.

Site

'Arnold Hauser'. Em: http://www.dictionaryofarthistorians.org/hausera.htm (04/08/2010).

Recebido em 29/09/2010

Aprovado em 08/10/2010 